\title{
Germline truncating-mutations in BRCA1 and MSH6 in a patient with early onset endometrial cancer
}

\author{
Karin Kast ${ }^{1 *}$, Teresa M Neuhann ${ }^{2,3 \dagger}$, Heike Görgens ${ }^{4}$, Kerstin Becker ${ }^{2}$, Katja Keller ${ }^{1}$, Barbara Klink ${ }^{2}$, Daniela Aust ${ }^{5}$, \\ Wolfgang Distler', Evelin Schröck ${ }^{2}$ and Hans K Schackert ${ }^{4}$
}

\begin{abstract}
Background: Hereditary Breast and Ovarian Cancer Syndrome (HBOCS) and Hereditary Non-Polyposis Colorectal Cancer Syndrome (HNPCC, Lynch Syndrome) are two tumor predisposition syndromes responsible for the majority of hereditary breast and colorectal cancers. Carriers of both germline mutations in breast cancer genes BRCA1 or BRCA2 and in mismatch repair (MMR) genes MLH1, MSH2, MSH6 or PMS2 are very rare.

Case presentation: We identified germline mutations in BRCA1 and in MSH6 in a patient with increased risk for $\mathrm{HBOC}$ diagnosed with endometrial cancer at the age of 46 years.

Conclusions: Although carriers of mutations in both MMR and BRCA genes are rare in Caucasian populations and anamnestical and histopathological findings may guide clinicians to identify these families, both syndromes can only be diagnosed through a complete gene analysis of the respective genes.
\end{abstract}

\section{Background}

Hereditary Breast and Ovarian Cancer Syndrome (HBOCS) is an autosomal dominantly inherited disease caused by mutations in BRCA1 or BRCA2 and characterized by young age of onset, synchronous or metachronous disease, and a family history of first and second degree relatives with breast and/or ovarian cancer. Depending on the affected gene, the estimated lifetime risks range from $46-85 \%$ for breast and $11-53 \%$ for ovarian cancer [1,2].

Lynch syndrome (hereditary non-polyposis colorectal cancer, HNPCC), is also an autosomal dominant tumor predisposition caused by germline mutations in DNA mismatch repair (MMR) genes $M L H 1, M S H 2, M S H 6$ or PMS2 with a life-time risk for colorectal cancer (CRC) of up to $80 \%$ and considerably increased risk of developing a broad spectrum of extracolonic malignancies including, among others, endometrial cancer (EC), stomach cancer and ovarian cancer $[3,4]$. In females, the cumulative risk

\footnotetext{
* Correspondence: karin.kast@uniklinikum-dresden.de

†Equal contributors

${ }^{1}$ Department of Gynecology and Obstetrics, University Hospital Carl Gustav

Carus, Technische Universität Dresden, Dresden, Germany

Full list of author information is available at the end of the article
}

for $\mathrm{EC}$ is $17-57 \%$ and almost equally high for CRC [5-8]. In MSH6 gene mutation carriers, CRC and ovarian cancer risks are lower [9]. However, $M S H 6$ is only affected in a small fraction of all MMR gene mutation carriers $[6,8]$.

Little is known about the phenotype of families with double mutations causing both HNPCC and HBOCS. Therefore, we report on a female index patient in a family fulfilling the criteria for HBOCS which developed endometrial cancer at age 46 and was identified as a double heterozygous germline mutation carrier.

\section{Case presentation}

The index patient of the family (individual III:1) was diagnosed with early stage endometrioid endometrial cancer at the age of 46 years, thus almost meeting the original Bethesda Guideline 4 [10]. She was referred to our Center for Hereditary Breast and Ovarian Cancer because of the early demise of her sister (III:2) due to triple negative breast cancer at the age of 33 years. Likewise, her mother (II:2) suffered from triple negative breast cancer at the age of 56. Her maternal aunt (II:5) had papillary-serous ovarian cancer at the age of 43 and additionally had been diagnosed with cervical squamous cell carcinoma at the age of 40 . Moreover, the patient

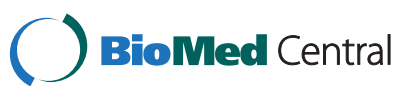


reported that her maternal grandfather I:1 had died of gastric cancer at the age of 67 years (no histologic or pathologic report were available). Four further maternal aunts and uncles and all of their children had not been reported for malignant diseases. One case of abdominal cancer of unknown origin (II:13) was reported in the paternal pedigree (Figure 1). All family members with breast or ovarian cancer had died. After counseling of the index patient and obtaining informed consent, analysis of the breast cancer genes BRCA1 and BRCA2 and testing for HNPCC was performed.

DNA-analysis of BRCA genes 1 and 2 was carried out by pre-screening of DNA extracted from lymphocytes of the index patient (III:1) with DHPLC (Denaturing High Performance Liquid Chromatography) using the WAVE ${ }^{\circledR}$ System 2100 (Transgenomic Ltd, United Kingdom) as described elsewhere [11]. Sanger sequencing of suspect fragments revealed the pathogenic BRCA1 mutation c.213-12A>G, p.Arg71SerfsX21. This nucleotide change is predicted to form a cryptic splice site resulting in the addition of 11 nucleotides to the BRCA1 transcript and a truncated protein [12]. Immunohistochemical staining (IHC) of MMR proteins MLH1, MSH2, MSH6 and PMS2 was carried out on formalin-fixed, paraffin-embedded tumor sections of the endometrial cancer of individual III:1 as described elsewhere [13]. Loss of expression of MSH6 was identified. Consequently, sequencing of the MSH6 gene was performed using primers and conditions described elsewhere [14], which revealed the pathogenic mutation c.515_516insT, p.Ile172fsX10.

The index patient (III:1) was thus identified as a carrier of pathogenic germline mutations in both $B R C A 1$ and MSH6. At the time of counseling she was 51 years of age. The endometrial cancer had been diagnosed at stage pT1a pNx G3 (FIGO IA) and was treated with hysterectomy, bilateral adnexectomy and resection of the upper proximal part of the vagina. Although facing a lifelong estimated risk for breast cancer of up to 80\% [2] she decided against preventive surgery. In addition to breast cancer surveillance, screening exams for HNPCCassociated tumors according to the German HNPCC Consortium [15] have been regularly performed in the last three years without pathological findings.

Her sister (III:3) and her nieces (IV:5 and IV:6) underwent predictive testing for the BRCA1 mutation of which IV:5 was identified to be a carrier. The sister (III:3) of the index patient and one niece (IV:5) were tested for the familial MSH6 mutation and none of them carries the mutation. At the time of writing this article, no further predictive testings have been carried out in other family members.

\section{Conclusions}

To date, only two families with co-occurrence of a MMR and BRCA1/BRCA2 mutation have been reported $[16,17]$. Thiffault et al. described two protein truncating mutations in $M S H 2$ and $B R C A 2$ identified in one female individual with breast cancer at the age of 32 and colon polyps at the age of 40. The patient's father (who had died at the age of 36 years) was an obligate carrier of both mutations and had CRC at 32 years. The female patient described by Borg et al. carried two MLH1 missense mutations (one of which segregating with familial, Lynch syndrome associated tumors) plus a BRCA1 mutation, being diagnosed with breast cancer at the age of 35 years. The reported tumors in these patients and the hereby reported case do not exceed the spectrum of HBOCS/HNPCC associated malignancies and are within

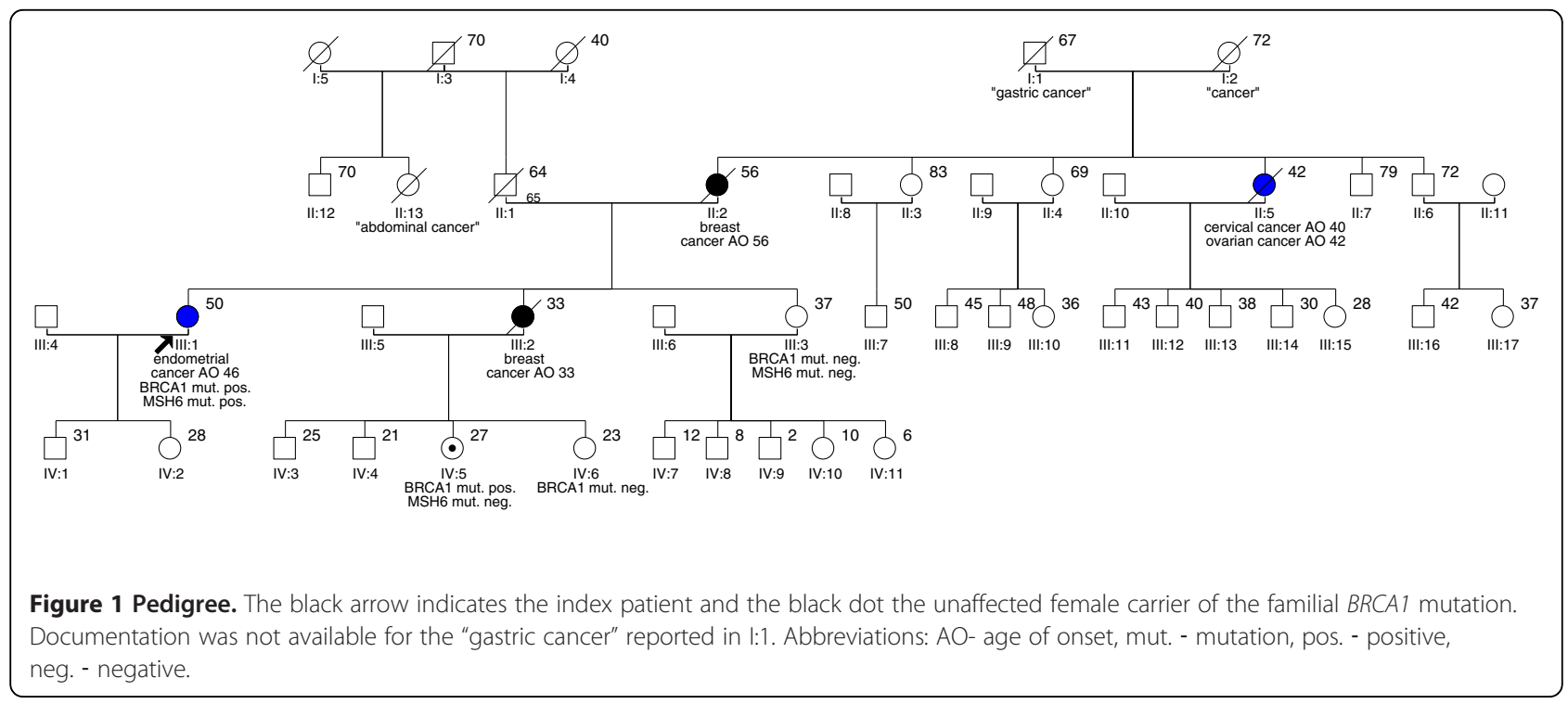


the expected age range of disease onset for carriers of a germline mutation in the respective MMR or BRCA genes alone.

In our family, the only Lynch syndrome associated malignancy was the EC in the index patient. Although three other cancers in both family branches (I:1, I:2, II:13) have been described, no proof of the tumor origin and/or pathology findings were available. It cannot be determined from the pedigree whether the MSH6 mutation originates from the maternal or paternal side. Since it is unlikely that the MSH6 mutation represents a de novo mutation, the low frequency of Lynch Syndrome associated cancers in both branches of the family may be due to reduced penetrance of MSH6 mutations $[8,9,18]$. So far, only two members of the family consented for predictive testing for the MSH6 mutation, none of which carried the mutation.

No consensus exists regarding the association of breast cancer with Lynch Syndrome. Although MSI has been described in most breast cancers of HNPCC kindreds, the risk for breast cancer is not elevated in most families [5,19-23]. However, a recent prospective study revealed an almost four-fold increase of breast cancer incidence in carriers of a mutation in the HNPCC-genes [24]. Moreover, Scott et al. reported on a significant overrepresentation of breast cancers in $M L H 1$ mutation carriers [25].

Triple negativity has been shown to be strongly associated with mutation carrier status of BRCA1 [26]. Thus, two triple negative breast cancers and the presence of an ovarian cancer strongly suggested a $B R C A 1$-associated disease in this family (Figure 1). Furthermore, a slightly increased risk for uterine and cervical cancer as well as colorectal cancer has also been reported for BRCA1 mutation carriers [27]. The uterine cancer of III:1 could therefore be misinterpreted as caused by the BRCA1 germline mutation. Nevertheless, HBOCS-associated uterine cancers tend to be of serous papillary type, whereas HNPCC-associated uterine cancers typically are of endometrial type, as in our case [28]. Proven by loss of expression of MSH6 the EC in patient III:1 is due to the germline MSH6 mutation. Additionally, the above mentioned higher rate of cervical cancers may be due to the interaction of the HPV oncogenes E6 and E7 with $B R C A 1$, which has been shown to render the cervix more susceptible to cancer [29].

The incidence of ovarian cancer in HBOCS is higher than in Lynch Syndrome. Additionally, BRCA1-associated ovarian cancers often show high grade serous histology, whereas HNPCC-associated ovarian cancers often display endometrioid histology $[23,30]$. Therefore, the ovarian cancer of individual II:5 was most probably BRCA1-associated.

It can be assumed that revised Bethesda Guidelines recommendations for the identification of colorectal tumors that should be tested for MSI, sometimes fail to identify individuals with HNPCC. To avoid nonidentification of HNPCC-patients it might be reasonable to screen both, colorectal and endometrial cancer tumor specimens for MMR-defect. Interestingly, this topic has been discussed at least for colorectal cancer at the HNPCC workshop conducted by the NCI in Bethesda, MD in 2002. Although participants voted to keep less than 60 years of age in the guideline 3 there was no consensus on whether to include the age criteria [4].

Data from the Robert Koch Institute German Cancer Registry (http://www.rki.de) indicate that the incidence of HNPCC associated cancers such as colorectal, small bowel, urinary tract, and endometrial cancer is about $6 \%$ in the German population. Assuming that $5 \%$ of these tumors are caused by MMR gene mutations with a penetrance of $80 \%$, the allele frequency in the German population is $0.38 \%$ [31]. Incidence of breast cancer is 9.53\% in the German female population. On the assumption that $5 \%$ of these tumors are caused by $B R C A 1$ or $B R C A 2$ mutations with a penetrance of $85 \%$ and that the allele frequency is similar in the male population, the allele frequency in the whole German population is $0.6 \%$ $[32,33]$. Therefore, the probability to be a carrier of both mutations in breast cancer genes and MMR genes is $1 / 167 \times 1 / 260 \times 1 / 4=1 / 174.800$, which sums up to 470 carriers of both alleles in the German population. Since allele frequencies are similar in Western populations the frequency of carriers of both alleles may be up to 5.7 per one million individuals.

Although carriers of mutations in both MMR and BRCA genes are rare in Caucasian populations, anamnestical and histopathological findings may guide clinicians to identify these families. Firstly, meeting both Bethesda Guidelines and HBOCS Criteria may raise suspicion of both syndromes in one family. Secondly, this may be substantiated by specific histological findings in available tumors, such as triple negative breast cancers (BRCA1associated), high grade papillary serous ovarian cancer (BRCA1- and 2-associated), endometrioid cancer of the uterus (MMR-gene-associated) and microsatellite instability (MMR-gene-associated). Finally, both syndromes can only be diagnosed through a complete gene analysis of the respective genes.

\section{Consent}

Written informed consent was obtained from the index patient III: 1 and from relative IV:5 for publication of this case report and any accompanying images.

\section{Competing interests}

The authors declare that they have no competing interests.

\section{Authors' contributions}

Karin Kast worked on the concept and design of the study and wrote the manuscript, also contributing to the acquisition, analysis and interpretation of the data. Teresa Neuhann recruited the family, initiated the genetic 
diagnostics of the BRCA and HNPCC genes, suggested the publication of the case and contributed to the writing of the manuscript. Katja Keller, Kerstin Becker and Barbara Klink were involved in data acquisition and communication with the patients. Daniela Aust and Heike Görgens were fundamental for the analysis and interpretation of the data. Evelin Schröck contributed to the final manuscript and oversaw the genetic counseling. Wolfgang Distler approved the manuscript to be published. Hans K. Schackert advised and contributed to the concept, design and writing the manuscript, as well as to the analysis and interpretation of data. All authors read and approved the final manuscript.

\section{Acknowledgements}

Research support: German Cancer Aid (Deutsche Krebshilfe, grants no: 3641011021 and 108906). German Consortium of Hereditary Breast and Ovarian Cancer (GC-HBOC). German Consortium for Hereditary Colorectal Cancer. Patients of both databases.

\section{Author details}

'Department of Gynecology and Obstetrics, University Hospital Carl Gustav Carus, Technische Universität Dresden, Dresden, Germany. ${ }^{2}$ Institute for Clinical Genetics, Technische Universität Dresden, Dresden, Germany. ${ }^{3}$ Medical Genetic Center, Munich, Germany. ${ }^{4}$ Department of Surgical Research, University Hospital Carl Gustav Carus, Technische Universität Dresden, Dresden, Germany. Institute of Pathology, University Hospital Carl Gustav Carus, Technische Universität Dresden, Dresden, Germany.

Received: 22 June 2012 Accepted: 8 November 2012

Published: 20 November 2012

\section{References}

1. Antoniou A, Pharoah PD, Narod S, Risch HA, Eyfjord JE, Hopper JL, Loman N, Olsson $\mathrm{H}$, Johannsson O, Borg A, et al: Average risks of breast and ovarian cancer associated with BRCA1 or BRCA2 mutations detected in case Series unselected for family history: a combined analysis of 22 studies. Am J Hum Genet 2003, 72(5):1117-1130.

2. King MC, Marks JH, Mandell JB: Breast and ovarian cancer risks due to inherited mutations in BRCA1 and BRCA2. Science 2003, 302(5645):643-646.

3. Lynch HT, de la Chapelle A: Hereditary colorectal cancer. N Engl J Med 2003, 348(10):919-932.

4. Umar A, Boland CR, Terdiman JP, Syngal S, de la Chapelle A, Ruschoff J, Fishel R, Lindor NM, Burgart LJ, Hamelin R, et al: Revised Bethesda Guidelines for hereditary nonpolyposis colorectal cancer (Lynch syndrome) and microsatellite instability. J Natl Cancer Inst 2004, 96(4):261-268.

5. Aarnio M, Sankila R, Pukkala E, Salovaara R, Aaltonen LA, de la Chapelle A, Peltomaki P, Mecklin JP, Jarvinen HJ: Cancer risk in mutation carriers of DNA-mismatch-repair genes. Int J Cancer 1999, 81(2):214-218.

6. Baglietto L, Lindor NM, Dowty JG, White DM, Wagner A, Gomez Garcia EB, Vriends AH, Cartwright NR, Barnetson RA, Farrington SM, et al: Risks of Lynch syndrome cancers for MSH6 mutation carriers. J Natl Cancer Inst 2010, 102(3):193-201.

7. Dunlop MG, Farrington SM, Carothers AD, Wyllie AH, Sharp L, Burn J, Liu B, Kinzler KW, Vogelstein B: Cancer risk associated with germline DNA mismatch repair gene mutations. Hum Mol Genet 1997, 6(1):105-110

8. Bonadona V, Bonaiti B, Olschwang S, Grandjouan S, Huiart L, Longy M, Guimbaud R, Buecher B, Bignon YJ, Caron O, et al: Cancer risks associated with germline mutations in $\mathrm{MLH} 1, \mathrm{MSH}$, and $\mathrm{MSH} 6$ genes in Lynch syndrome. JAMA 2011, 305(22):2304-2310,

9. Plaschke J, Engel C, Kruger S, Holinski-Feder E, Pagenstecher C, Mangold E, Moeslein G, Schulmann K, Gebert J, von Knebel Doeberitz M, et al: Lower incidence of colorectal cancer and later age of disease onset in 27 families with pathogenic MSH6 germline mutations compared with families with MLH1 or MSH2 mutations: the German Hereditary Nonpolyposis Colorectal Cancer Consortium. J Clin Oncol 2004, 22(22):4486-4494.

10. Rodriguez-Bigas MA, Boland CR, Hamilton SR, Henson DE, Jass JR, Khan PM, Lynch H, Perucho M, Smyrk T, Sobin L, et al: A National Cancer Institute Workshop on Hereditary Nonpolyposis Colorectal Cancer Syndrome: meeting highlights and Bethesda guidelines. J Natl Cancer Inst 1997, 89(23):1758-1762.
11. Meindl A, German Consortium for Hereditary Breast and Ovarian Cancer: Comprehensive analysis of 989 patients with breast or ovarian cancer provides BRCA1 and BRCA2 mutation profiles and frequencies for the German population. Int J Cancer 2002, 97(4):472-480.

12. Hoffman JD, Hallam SE, Venne VL, Lyon E, Ward K: Implications of a novel cryptic splice site in the BRCA1 gene. Am J Med Genet 1998, 80(2):140-144

13. Plaschke J, Kruger S, Pistorius S, Theissig F, Saeger HD, Schackert HK: Involvement of hMSH6 in the development of hereditary and sporadic colorectal cancer revealed by immunostaining is based on germline mutations, but rarely on somatic inactivation. Int J Cancer 2002, 97(5):643-648

14. Plaschke J, Kruppa C, Tischler R, Bocker T, Pistorius S, Dralle H, Ruschoff J, Saeger HD, Fishel R, Schackert HK: Sequence analysis of the mismatch repair gene hMSH6 in the germline of patients with familial and sporadic colorectal cancer. Int J Cancer 2000, 85(5):606-613.

15. Engel C, Rahner N, Schulmann K, Holinski-Feder E, Goecke TO, Schackert HK, Kloor M, Steinke V, Vogelsang H, Moslein G, et al: Efficacy of annual colonoscopic surveillance in individuals with hereditary nonpolyposis colorectal cancer. Clin Gastroenterol Hepatol 2010, 8(2):174-182.

16. Borg A, Isola J, Chen J, Rubio C, Johansson U, Werelius B, Lindblom A: Germline BRCA1 and HMLH1 mutations in a family with male and female breast carcinoma. Int J Cancer 2000, 85(6):796-800.

17. Thiffault I, Hamel N, Pal T, McVety S, Marcus VA, Farber D, Cowie S, Deschenes J, Meschino W, Odefrey F, et al: Germline truncating mutations in both MSH2 and BRCA2 in a single kindred. Br J Cancer 2004, 90(2):483-491

18. Win AK, Jenkins MA, Buchanan DD, Clendenning M, Young JP, Giles GG, Goldblatt J, Leggett BA, Hopper JL, Thibodeau SN, et al: Determining the frequency of de novo germline mutations in DNA mismatch repair genes. J Med Genet 2011, 48(8):530-534.

19. Buerki N, Gautier L, Kovac M, Marra G, Buser M, Mueller H, Heinimann K: Evidence for breast cancer as an integral part of Lynch syndrome. Genes Chromosomes Cancer 2012, 51(1):83-91.

20. Muller A, Edmonston TB, Corao DA, Rose DG, Palazzo JP, Becker H, Fry RD, Rueschoff J, Fishel R: Exclusion of breast cancer as an integral tumor of hereditary nonpolyposis colorectal cancer. Cancer Res 2002, 62(4):1014-1019.

21. Shanley S, Fung C, Milliken J, Leary J, Barnetson R, Schnitzler M, Kirk J: Breast cancer immunohistochemistry can be useful in triage of some HNPCC families. Fam Cancer 2009, 8(3):251-255.

22. Walsh MD, Buchanan DD, Cummings MC, Pearson SA, Arnold ST, Clendenning M, Walters R, McKeone DM, Spurdle AB, Hopper JL, et al: Lynch syndrome-associated breast cancers: clinicopathologic characteristics of a case series from the colon cancer family registry. Clin Cancer Res 2010, 16(7):2214-2224.

23. Watson P, Vasen HF, Mecklin JP, Bernstein I, Aarnio M, Jarvinen HJ, Myrhoj T, Sunde L, Wijnen JT, Lynch HT: The risk of extra-colonic, extra-endometrial cancer in the Lynch syndrome. Int J Cancer 2008, 123(2):444-449.

24. Win AK, Young JP, Lindor NM, Tucker KM, Ahnen DJ, Young GP, Buchanan DD, Clendenning M, Giles GG, Winship I, et al: Colorectal and other cancer risks for carriers and noncarriers from families with a DNA mismatch repair gene mutation: a prospective cohort study. J Clin Oncol 2012, 30(9):958-964.

25. Scott RJ, McPhillips M, Meldrum CJ, Fitzgerald PE, Adams K, Spigelman AD, du Sart D, Tucker K, Kirk J: Hereditary nonpolyposis colorectal cancer in 95 families: differences and similarities between mutation-positive and mutation-negative kindreds. Am J Hum Genet 2001, 68(1):118-127.

26. Atchley DP, Albarracin CT, Lopez A, Valero V, Amos Cl, Gonzalez-Angulo AM, Hortobagyi GN, Arun BK: Clinical and pathologic characteristics of patients with BRCA-positive and BRCA-negative breast cancer. J Clin Oncol 2008, 26(26):4282-4288.

27. Thompson D, Easton DF: Cancer Incidence in BRCA1 mutation carriers. J Natl Cancer Inst 2002, 94(18):1358-1365.

28. Lavie O, Ben-Arie A, Segev Y, Faro J, Barak F, Haya N, Auslender R, Gemer O: BRCA germline mutations in women with uterine serous carcinoma-still a debate. Int J Gynecol Cancer 2010, 20(9):1531-1534.

29. Zhang Y, Fan S, Meng Q, Ma Y, Katiyar P, Schlegel R, Rosen EM: BRCA1 interaction with human papillomavirus oncoproteins. J Biol Chem 2005, 280(39):33165-33177.

30. Gilks CB, Prat J: Ovarian carcinoma pathology and genetics: recent advances. Hum Pathol 2009, 40(9):1213-1223. 
31. Lynch $H T$, de la Chapelle A: Genetic susceptibility to non-polyposis colorectal cancer. J Med Genet 1999, 36(11):801-818.

32. Claus EB, Schildkraut JM, Thompson WD, Risch NJ: The genetic attributable risk of breast and ovarian cancer. Cancer 1996, 77(11):2318-2324.

33. Narod SA, Foulkes WD: BRCA1 and BRCA2: 1994 and beyond. Nat Rev Cancer 2004, 4(9):665-676.

doi:10.1186/1471-2407-12-531

Cite this article as: Kast et al:: Germline truncating-mutations in BRCA1 and MSH6 in a patient with early onset endometrial cancer. BMC Cancer 2012 12:531.

\section{Submit your next manuscript to BioMed Central} and take full advantage of:

- Convenient online submission

- Thorough peer review

- No space constraints or color figure charges

- Immediate publication on acceptance

- Inclusion in PubMed, CAS, Scopus and Google Scholar

- Research which is freely available for redistribution 